Supplement of

\title{
Secondary inorganic aerosols in Europe: sources and the significant influence of biogenic VOC emissions, especially on ammonium nitrate
}

Sebnem Aksoyoglu et al.

Correspondence to: Sebnem Aksoyoglu (sebnem.aksoyoglu@psi.ch)

The copyright of individual parts of the supplement might differ from the CC BY 3.0 License. 


\section{Supplementary Material}

Table S1: Reactions and rate constants for biogenic VOCs in the CB05 mechanism (ENVIRON, 2011)

\begin{tabular}{|c|c|c|}
\hline $\begin{array}{l}\text { Isoprene } \\
\text { reactions }\end{array}$ & Reaction products & $\begin{array}{l}\mathrm{k}_{298} \\
\left(\mathrm{ppm}^{-\mathrm{n}} \min ^{-1}\right)\end{array}$ \\
\hline $\mathrm{ISOP}+\mathrm{O}$ & $\begin{array}{l}\text { 0.75 ISPD + } 0.5 \mathrm{FORM}+0.25 \mathrm{XO} 2+0.25 \mathrm{HO} 2+0.25 \mathrm{CXO} 3+ \\
0.25 \mathrm{PAR}\end{array}$ & $5.318 \mathrm{E}+04$ \\
\hline $\mathrm{ISOP}+\mathrm{OH}$ & $\begin{array}{l}0.912 \text { ISPD }+0.629 \text { FORM }+0.991 \text { XO2 + } 0.912 \mathrm{HO} 2+0.088 \\
\text { XO2N }\end{array}$ & $1.473 \mathrm{E}+05$ \\
\hline $\mathrm{ISOP}+\mathrm{O} 3$ & $\begin{array}{l}0.65 \mathrm{ISPD}+0.6 \mathrm{FORM}+0.2 \mathrm{XO} 2+0.066 \mathrm{HO} 2+0.266 \mathrm{OH}+0.2 \\
\mathrm{CXO} 3+0.15 \mathrm{ALDX}+0.35 \mathrm{PAR}+0.066 \mathrm{CO}\end{array}$ & $1.898 \mathrm{E}-02$ \\
\hline ISOP+NO3 & $\begin{array}{l}0.2 \mathrm{ISPD}+0.8 \mathrm{NTR}+\mathrm{XO} 2+0.8 \mathrm{HO} 2+0.2 \mathrm{NO} 2+0.8 \mathrm{ALDX}+ \\
\text { 2.4 PAR }\end{array}$ & $9.954 \mathrm{E}+02$ \\
\hline $\mathrm{ISOP}+\mathrm{NO} 2$ & $\begin{array}{l}0.2 \mathrm{ISPD}+0.8 \mathrm{NTR}+\mathrm{XO} 2+0.8 \mathrm{HO} 2+0.2 \mathrm{NO}+0.8 \mathrm{ALDX}+ \\
\text { 2.4 PAR }\end{array}$ & $2.216 \mathrm{E}-04$ \\
\hline $\mathrm{ISPD}+\mathrm{OH}$ & $\begin{array}{l}\text { 1.565 PAR + 0.167 FORM }+0.713 \mathrm{XO} 2+0.503 \mathrm{HO} 2+0.334 \mathrm{CO} \\
+0.168 \mathrm{MGLY}+0.252 \mathrm{ALD} 2+0.21 \mathrm{C} 2 \mathrm{O} 3+0.25 \mathrm{CXO} 3+0.12 \\
\text { ALDX }\end{array}$ & $4.963 \mathrm{E}+04$ \\
\hline $\mathrm{ISPD}+\mathrm{O} 3$ & $\begin{array}{l}0.114 \mathrm{C} 2 \mathrm{O} 3+0.15 \mathrm{FORM}+0.85 \mathrm{MGLY}+0.154 \mathrm{HO} 2+0.268 \\
\mathrm{OH}+0.064 \mathrm{XO} 2+0.02 \mathrm{ALD} 2+0.36 \mathrm{PAR}+0.225 \mathrm{CO}\end{array}$ & $1.049 \mathrm{E}-02$ \\
\hline ISPD+NO3 & $\begin{array}{l}0.357 \mathrm{ALDX}+0.282 \mathrm{FORM}+1.282 \mathrm{PAR}+0.925 \mathrm{HO} 2+0.643 \\
\mathrm{CO}+0.85 \mathrm{NTR}+0.075 \mathrm{CXO} 3+0.075 \mathrm{XO} 2+0.15 \mathrm{HNO} 3\end{array}$ & $1.477 \mathrm{E}+00$ \\
\hline ISPD & $\begin{array}{l}0.333 \mathrm{CO}+0.067 \mathrm{ALD} 2+0.9 \mathrm{FORM}+0.832 \mathrm{PAR}+1.033 \mathrm{HO} 2+ \\
0.7 \mathrm{XO} 2+0.967 \mathrm{C} 2 \mathrm{O} 3\end{array}$ & photolysis \\
\hline \multicolumn{3}{|l|}{$\begin{array}{l}\text { Terpene } \\
\text { reactions }\end{array}$} \\
\hline TERP + O & 0.15 ALDX +5.12 PAR & $5.318 \mathrm{E}+04$ \\
\hline $\mathrm{TERP}+\mathrm{OH}$ & $\begin{array}{l}0.75 \mathrm{HO} 2+1.25 \mathrm{XO} 2+0.25 \mathrm{XO} 2 \mathrm{~N}+0.28 \mathrm{FORM}+1.66 \mathrm{PAR}+ \\
0.47 \mathrm{ALDX}\end{array}$ & $9.997 \mathrm{E}+04$ \\
\hline $\mathrm{TERP}+\mathrm{O} 3$ & $\begin{array}{l}0.57 \mathrm{OH}+0.07 \mathrm{HO} 2+0.76 \mathrm{XO} 2+0.18 \mathrm{XO} 2 \mathrm{~N}+0.24 \mathrm{FORM}+ \\
0.001 \mathrm{CO}+7 \mathrm{PAR}+0.21 \mathrm{ALDX}+0.39 \mathrm{CXO} 3\end{array}$ & $1.128 \mathrm{E}-01$ \\
\hline TERP+NO3 & $\begin{array}{l}0.47 \mathrm{NO} 2+0.28 \mathrm{HO} 2+1.03 \mathrm{XO} 2+0.25 \mathrm{XO} 2 \mathrm{~N}+0.47 \mathrm{ALDX}+ \\
0.53 \mathrm{NTR}\end{array}$ & $9.833 \mathrm{E}+03$ \\
\hline
\end{tabular}

$\begin{array}{ll}\mathrm{OH} & \text { Hydroxyl radical } \\ \mathrm{HO} 2 & \text { Hydroperoxy radical } \\ \mathrm{NO} 2 & \text { Nitrogen dioxide } \\ \mathrm{NO} 3 & \text { Nitrate radical } \\ \mathrm{HNO} 3 & \text { Nitric acid } \\ \text { NTR } & \text { Organic nitrate }\left(\mathrm{RNO}_{3}\right) \\ \mathrm{CO} & \text { Carbon monoxide } \\ \text { FORM } & \text { Formaldehyde } \\ \text { ALD2 } & \text { Acetaldehyde } \\ \text { ALDX } & \text { Propionaldehyde and higher aldehydes } \\ \text { PAR } & \text { Paraffin carbon bond (C-C) } \\ \text { XO2 } & \text { NO to NO2 conversion from alkylperoxy (RO2) radical } \\ \text { XO2N } & \text { NO to organic nitrate conversion from alkylperoxy (RO2) radical } \\ \text { MGLY } & \text { Methylglyoxal and other aromatic products } \\ \text { C2O3 } & \text { Acetylperoxy radical } \\ \text { CXO3 } & \text { C3 and higher acylperoxy radicals } \\ \text { ISOP } & \text { Isoprene } \\ \text { ISPD } & \text { Isoprene product (lumped methacrolein, methyl vinyl ketone, etc.) } \\ \text { TERP } & \text { Terpene }\end{array}$


Table S2: Biogenic SOA precursor reactions included in CAMx (ENVIRON, 2011)

\begin{tabular}{llll}
\hline Precursor & Reaction & CG (condensable gas) products & $\mathrm{k}_{298}\left(\mathrm{ppm}^{-\mathrm{n}} \mathrm{min}^{-1}\right)$ \\
\hline Isoprene & ISP + O & none & $5.32 \mathrm{E}+04$ \\
& ISP + OH & $0.015 \mathrm{CG} 3+0.12 \mathrm{CG} 4$ & $1.47 \mathrm{E}+05$ \\
& ISP + O3 & none & $1.90 \mathrm{E}-02$ \\
& ISP + NO3 & none & $9.96 \mathrm{E}+02$ \\
\hline Terpenes & TRP + O & 0.065 CG5 + 0.29 CG6 & $4.12 \mathrm{E}+04$ \\
& TRP + OH & 0.065 CG5 + 0.29 CG6 & $7.76 \mathrm{E}+04$ \\
& TRP + O3 & 0.065 CG5 + 0.29 CG6 & $1.33 \mathrm{E}-01$ \\
& TRP + NO3 & 0.065 CG5 + 0.29 CG6 & $9.18 \mathrm{E}+03$ \\
\hline Sesquiterpenes & SQT + OH & 0.85 CG7 & $2.91 \mathrm{E}+05$ \\
& SQT + O3 & 0.85 CG7 & $1.71 \mathrm{E}+01$ \\
& SQT + NO3 & 0.85 CG7 & $2.81 \mathrm{E}+04$ \\
\hline
\end{tabular}




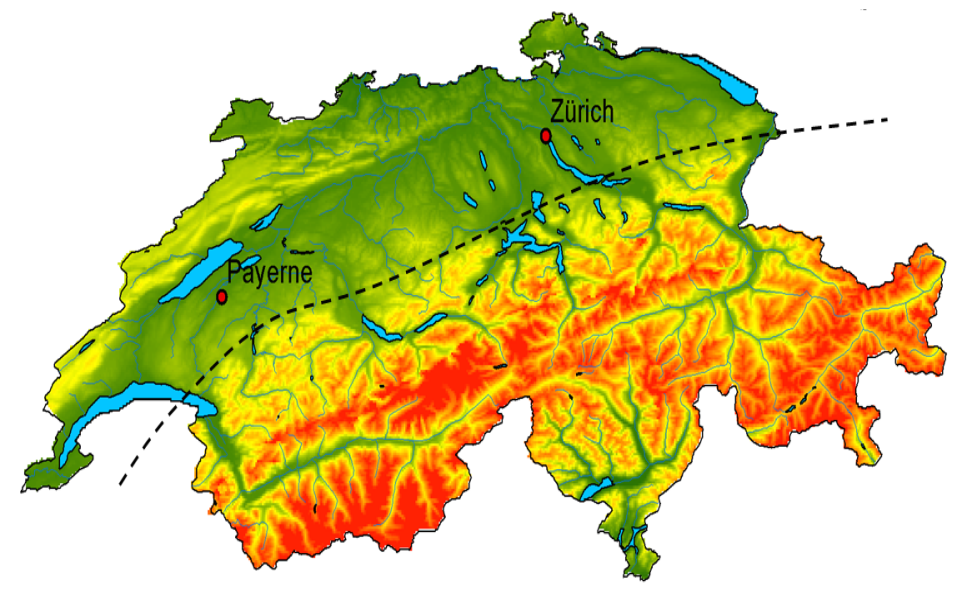

Figure S1: The Swiss Plateau (the region above the dashed line) used as receptor in PSAT calculations.

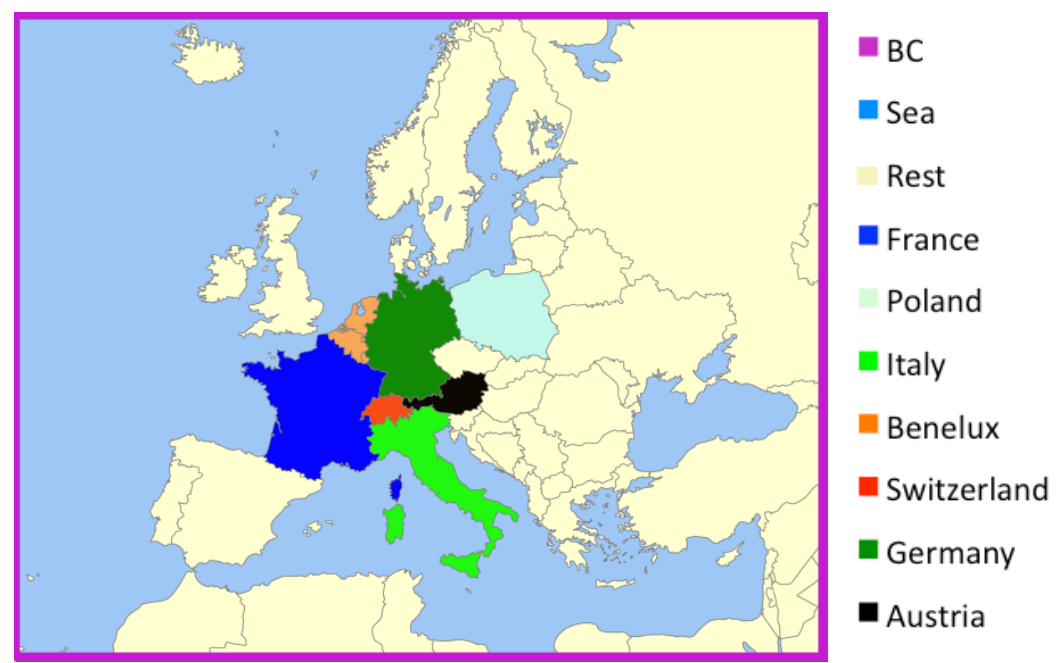

Figure S2: Source regions used in PSAT calculations. Note that this map was only used for illustration of the regions and their colors and it doesn't have the same projection used in the model simulations. 

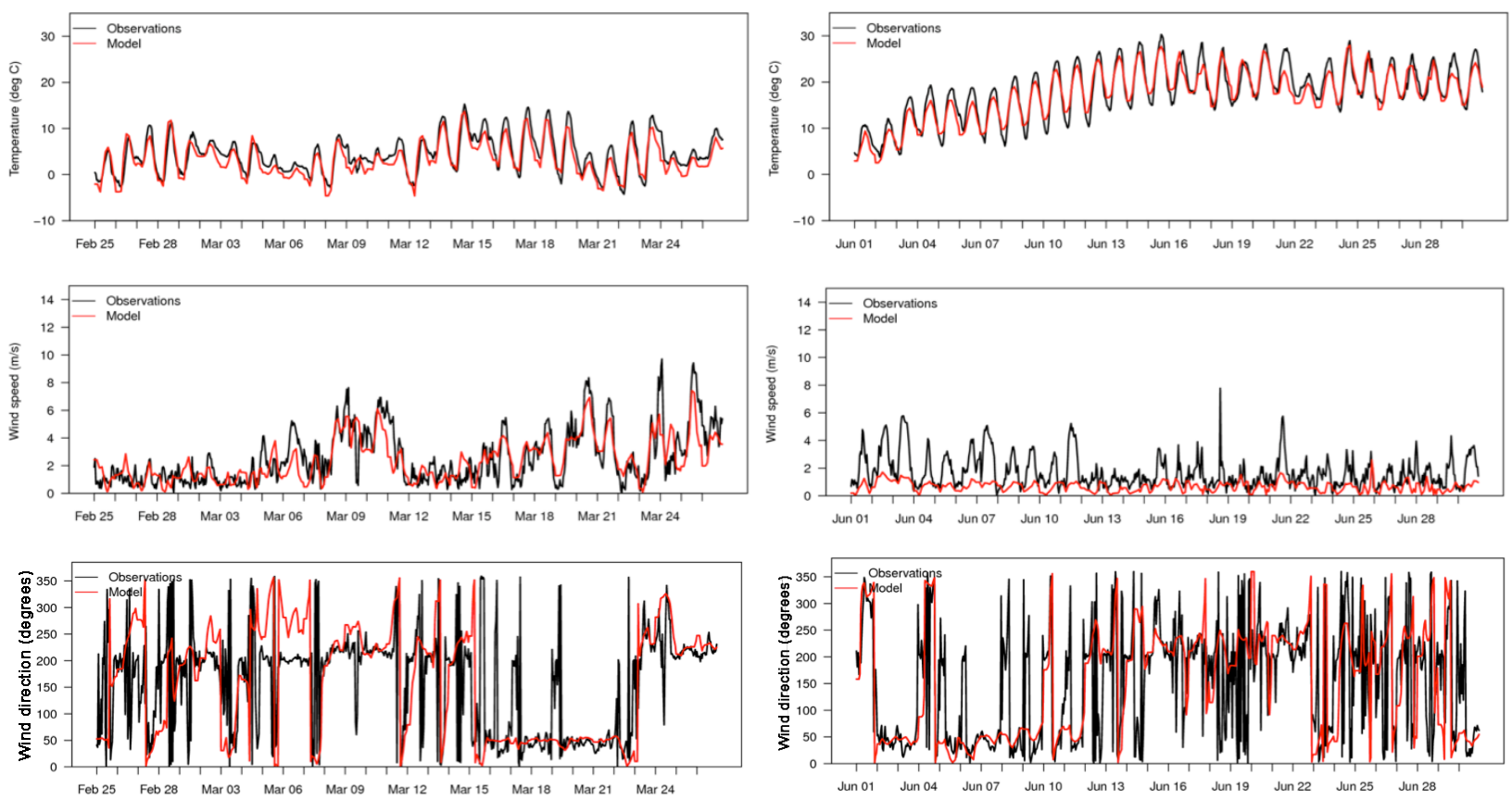

Figure S3: Modelled (red) and measured (black) temperature, wind speed and wind direction for the cold season in Feb-Mar 2009 (left) and the warm season in June 2006 (right) in Payerne, Switzerland.
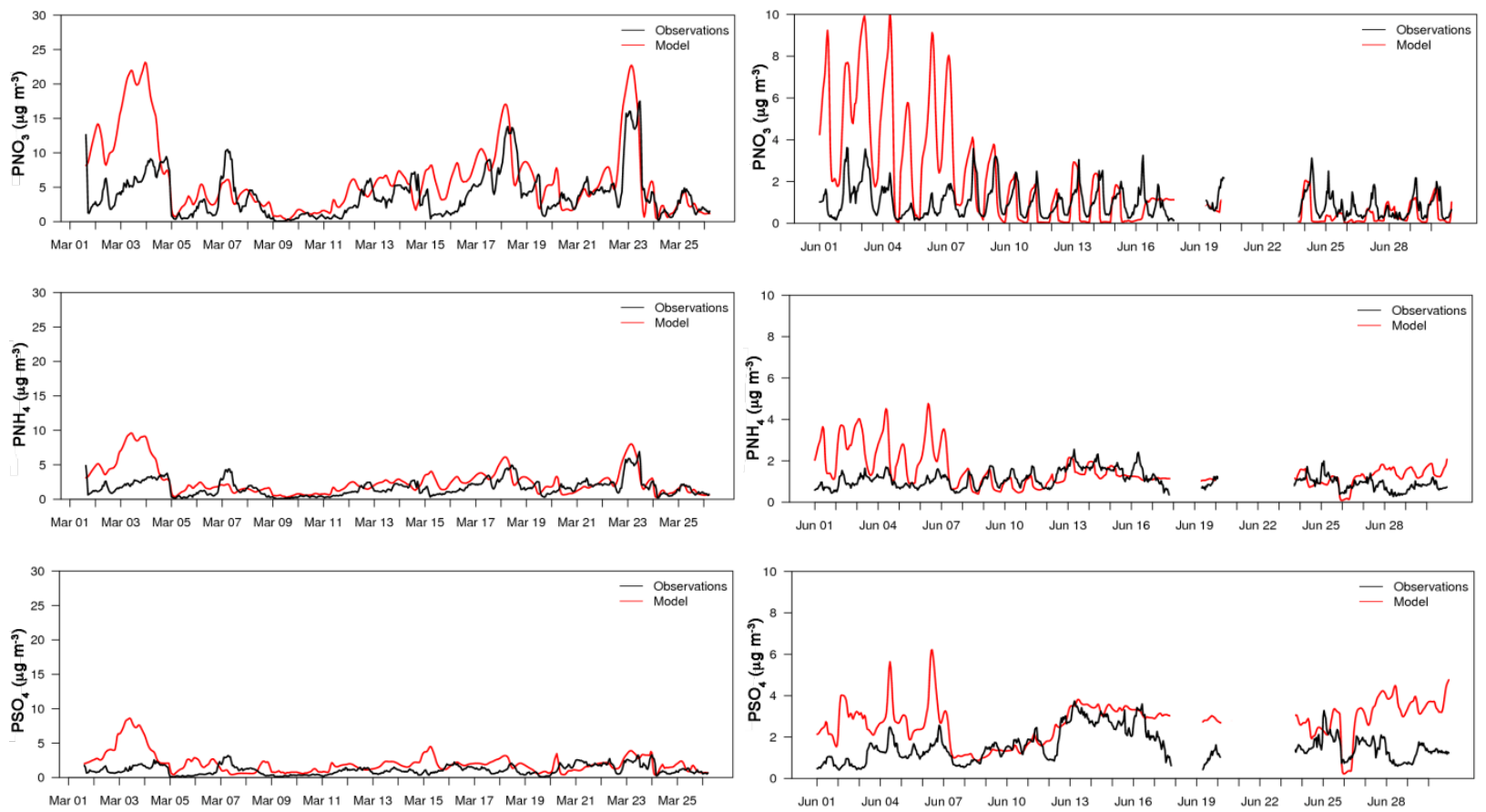

Figure S4: Modelled (red) and measured (black) nitrate $\left(\mathrm{PNO}_{3}\right)$, ammonium $\left(\mathrm{PNH}_{4}\right)$ and sulfate $\left(\mathrm{PSO}_{4}\right)$ for the cold season in Mar 2009 (left) and the warm season in June 2006 (right) in Payerne, Switzerland. 

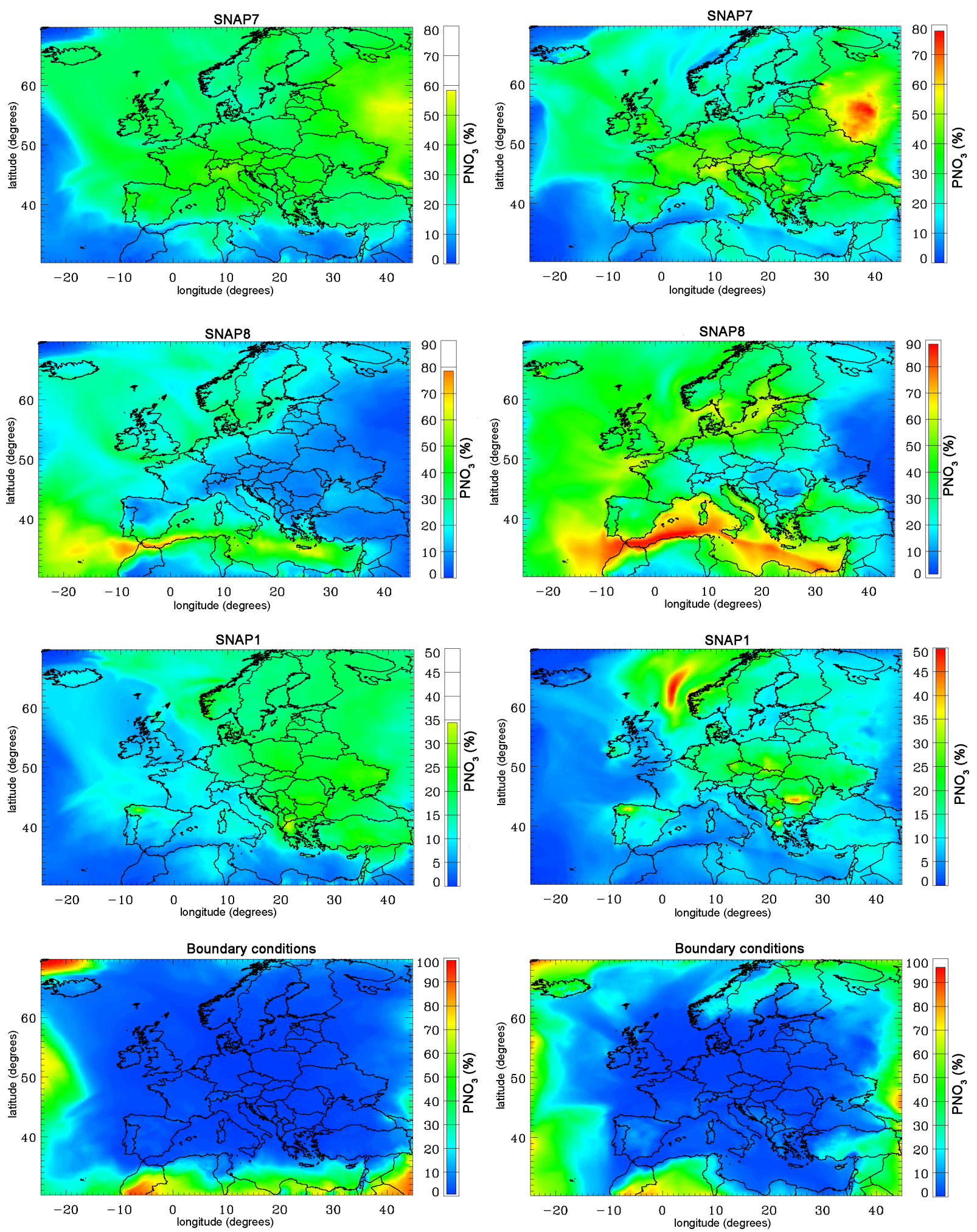

Figure S5: Relative contributions to $\mathrm{PNO}_{3}$ from road transport (SNAP7), ships (SNAP8), combustion in energy and transformation industries (SNAP1) and boundary conditions in February-March 2009 (left) and in June 2006 (right). 

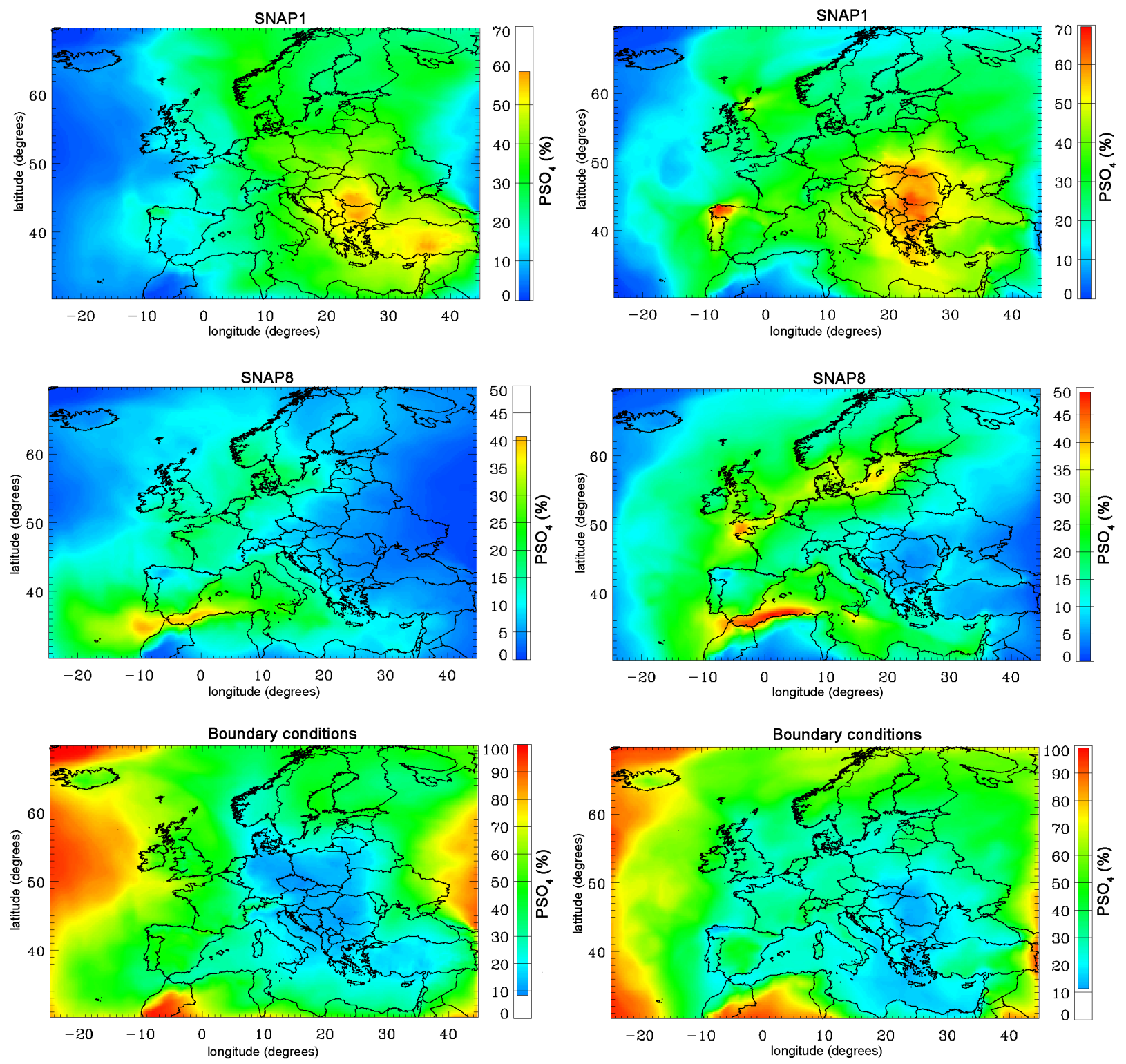

Figure S6: Relative contributions to $\mathrm{PSO}_{4}$ from combustion in energy and transformation industries (SNAP1), ships (SNAP8) and boundary conditions in February-March 2009 (left) and in June 2006 (right). 

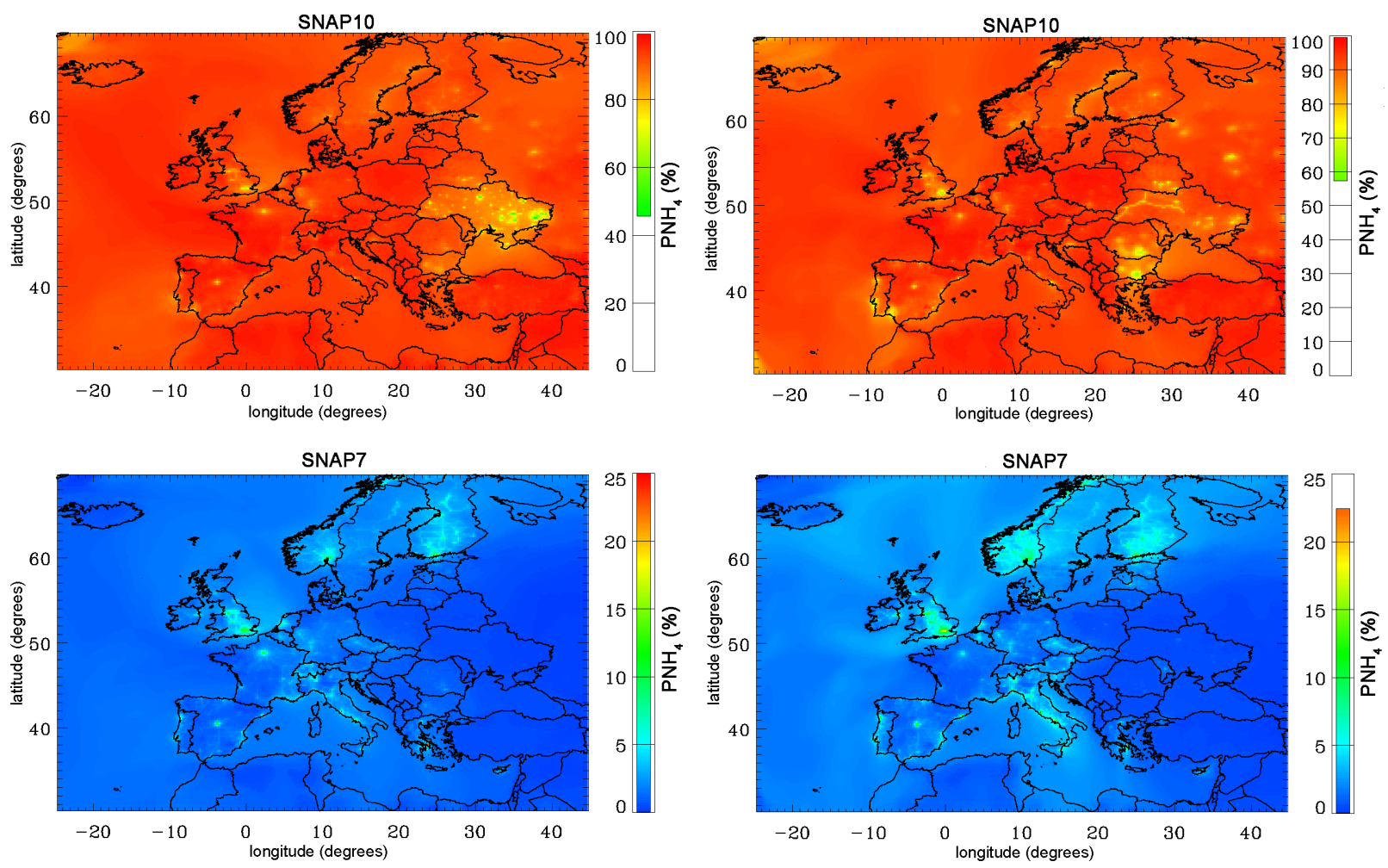

Figure S7: Relative contributions to $\mathrm{PNH}_{4}$ from agriculture (SNAP10) and road transport (SNAP7) in February-March 2009 (left) and in June 2006 (right). 

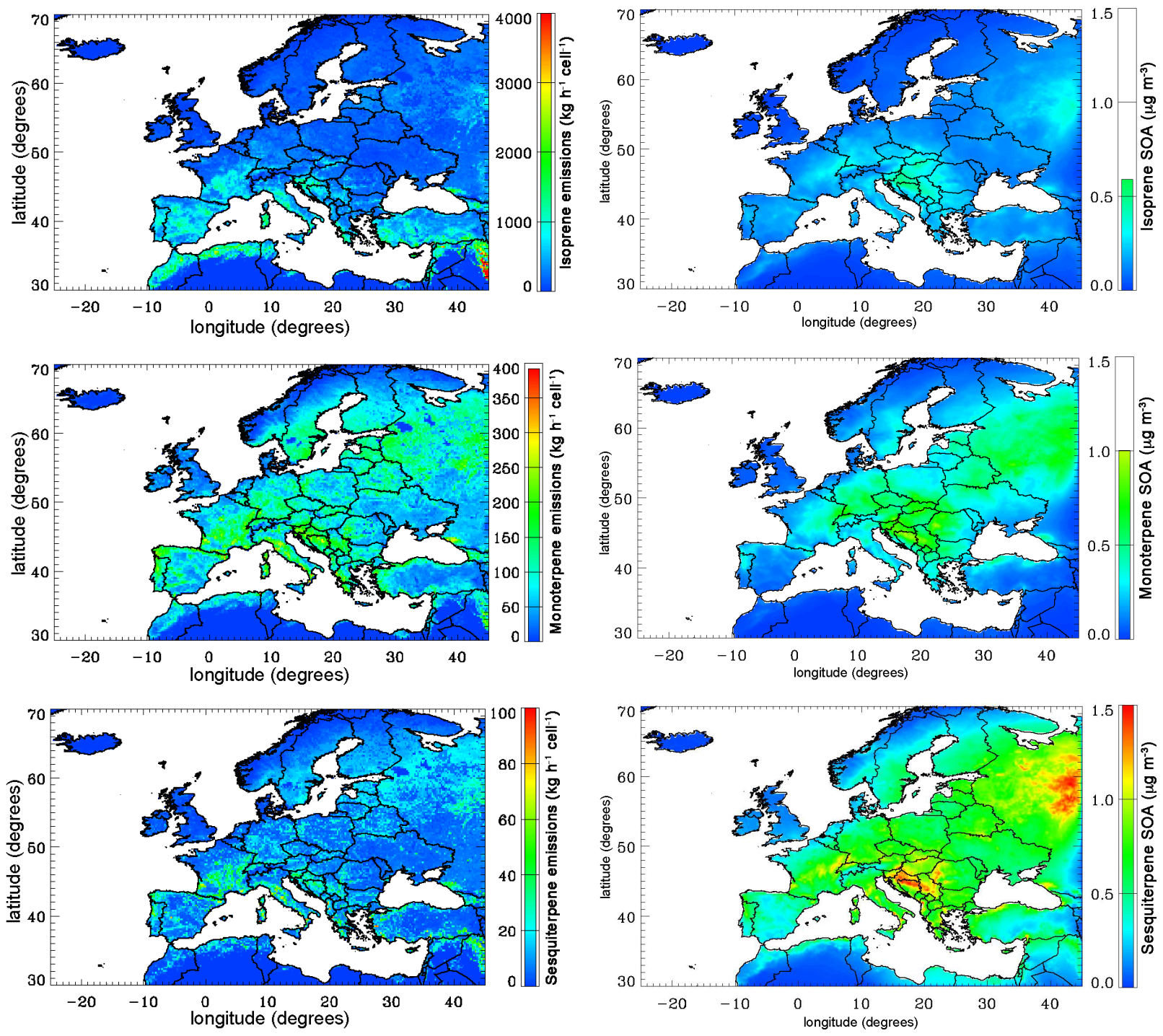

Figure S8: Monthly average emissions of biogenic species (left) and their SOA products (right); isoprene (top), monoterpenes (middle) and sesquiterpenes (bottom) in June 2006. 

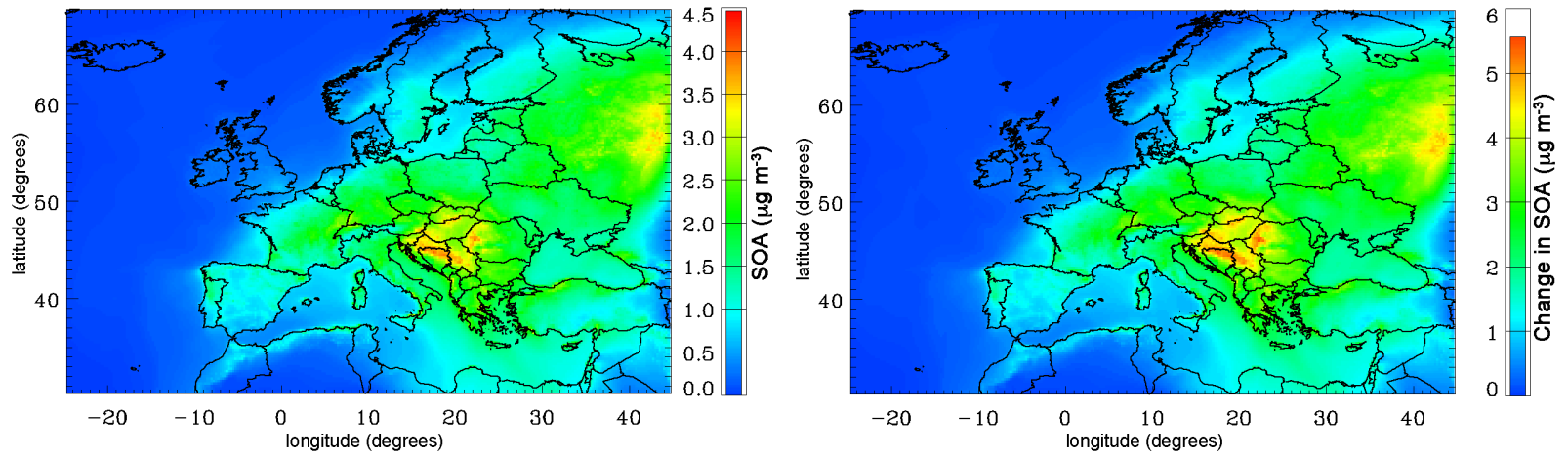

Figure S9: Total SOA concentrations in the base case (left) and changes in SOA when BVOC emissions were doubled (right) in June 2006.
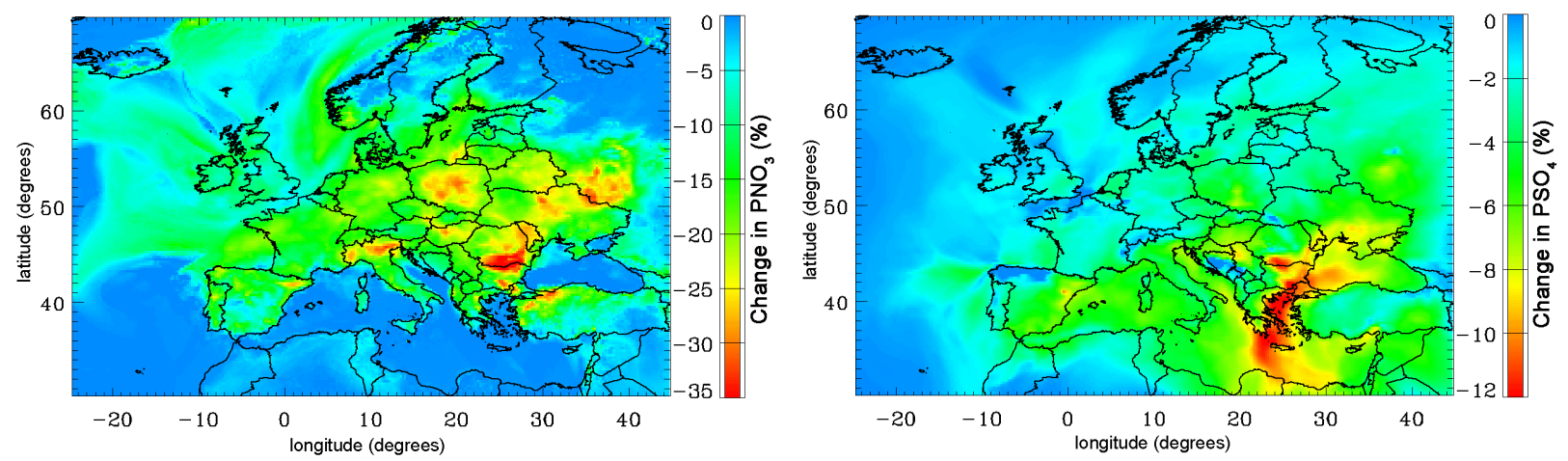

Figure S10: Relative changes in $\mathrm{PNO}_{3}$ (left) and $\mathrm{PSO}_{4}$ (right) concentrations in June 2006 when BVOC emissions were doubled.

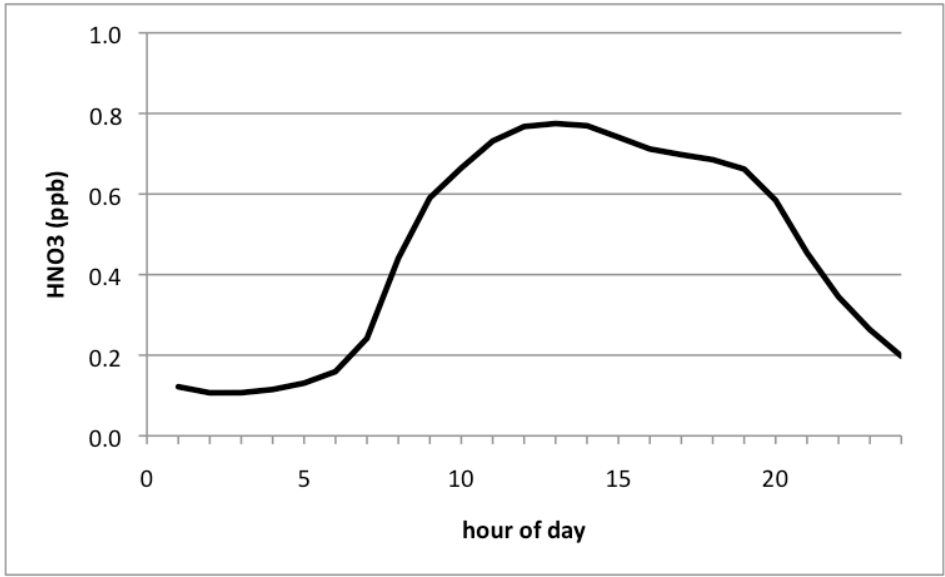

Figure S11: Diurnal cycle of modeled $\mathrm{HNO}_{3}$ concentrations (ppb) at Payerne (June 2006). 


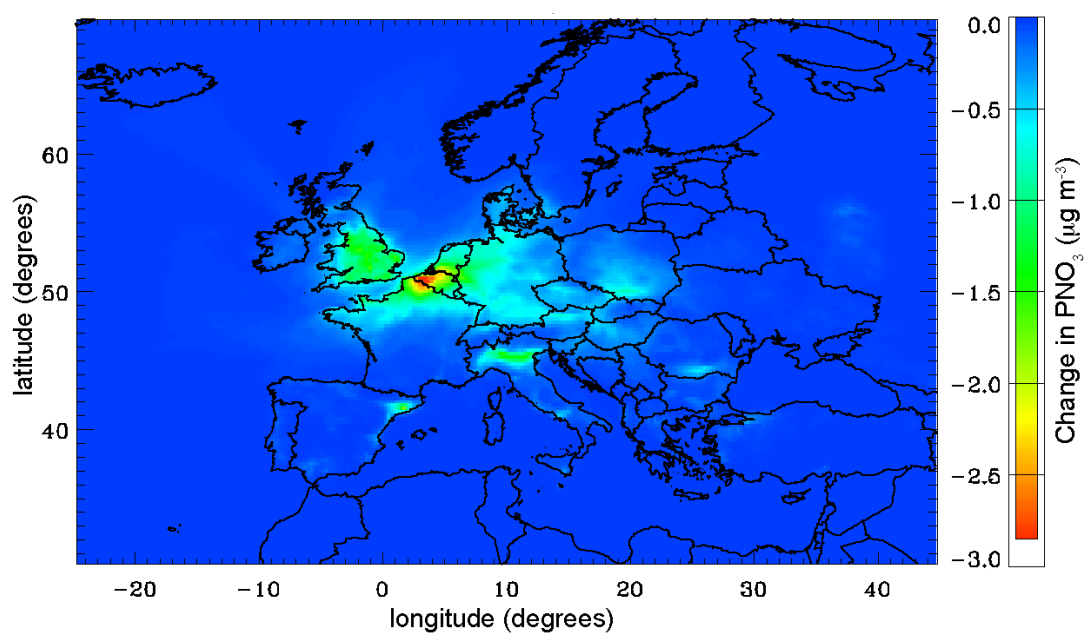

Figure S12: Change in $\mathrm{PNO}_{3}$ concentrations (in $\mu \mathrm{g} \mathrm{m}^{-3}$ ) in June 2006 when hydrolysis reaction of $\mathrm{N}_{2} \mathrm{O}_{5}$ was switched off.

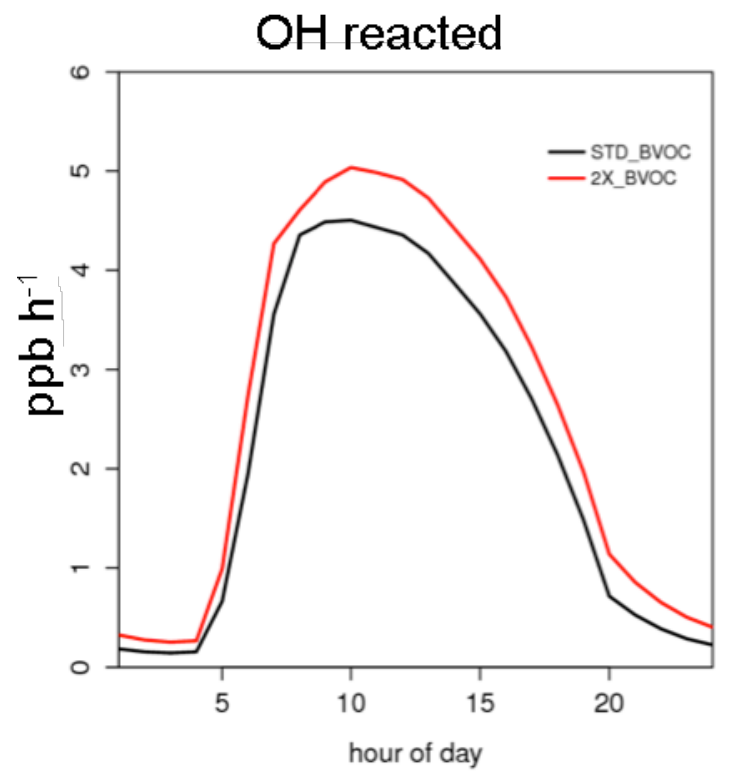

Figure S13: Changes in diurnal variation of reacted OH radical (June 2006, Payerne). Black: with standard BVOC emissions, red: with doubled BVOC emissions. 